\title{
Hexosamines stimulate apoptosis by altering SIRT1 action and levels in rodent pancreatic $\beta$-cells
}

\author{
Mathieu Lafontaine-Lacasse, Geneviève Doré and Frédéric Picard \\ Centre de recherche de l'Institut universitaire de cardiologie et de pneumologie de Québec, Laval University, Y3106 Pavillon Marguerite-d'Youville, \\ 2725 Chemin Ste-Foy, Québec, Québec, Canada G1V 4G5 \\ (Correspondence should be addressed to F Picard; Email: frederic.picard@criucpq.ulaval.ca)
}

\begin{abstract}
The activity and levels of SIRT1, which promotes cell survival in several models, are linked to glucose concentrations and cellular energy metabolism. The present study aimed to determine whether impaired Sirt1 activity is involved in the induction of apoptosis by the nutrientsensing hexosamine biosynthesis pathway (HBP). Pancreatic Nit-1, Rin-m5F, and Min6 $\beta$-cells were acutely treated at different doses and times with glucosamine, which enters and stimulates the HBP. Sirt1 levels were genetically modulated by retroviral infection. Expression levels, cellular localization, and activity of apoptosis-related markers were determined by $\mathrm{qPCR}$, immunoblotting, and co-immunoprecipitation. Glucosamine treatment dose- and time
\end{abstract}

dependently induced cell apoptosis in all cell lines studied. HBP stimulation time dependently modified SIRT1 protein levels, notably in the cytoplasm. This was concomitant with increased E2F1 binding to the $c-m \gamma c$ promoter. In both NIT-1 and min6 $\beta$-cells, genetic knockdown of Sirt1 expression resulted in higher susceptibility to HBPstimulated apoptosis, whereas overexpression of Sirt 1 had the opposite impact. These findings indicate that reduction of SIRT1 levels by hexosamines contributes to $\beta$-cell apoptosis. Methods to increase SIRT1 levels or activity could thus prevent the decrease in $\beta$-cell mass, notably that observed in type 2 diabetes.

Journal of Endocrinology (2011) 208, 41-49

\section{Introduction}

Hyperglycemia, occurring after a meal or during diabetes or aging, is detrimental to several systems, especially in sensitive tissues such as the brain and the pancreas, in which it has been shown that prolonged hyperglycemia leads to cell death through apoptotic signals. Pancreatic $\beta$-cells suffer from longterm high glucose levels via the induction of oxidative stress, stimulation of pro-apoptotic events, and ATP depletion from reduced glucose metabolism (Kaneto et al. 2001, Anello et al. 2004, Zachara \& Hart 2004). Although apoptosis has been established as the primary factor for reduced $\beta$-cell mass in type 2 diabetes (Hanley et al. 2010), the molecular mechanisms linking hyperglycemia and the induction of apoptotic gene expression have not been fully determined.

Glucose metabolism through the hexosamine biosynthesis pathway (HBP) has been hypothesized to mediate many of the adverse effects of hyperglycemia and to be involved in the pathogenesis of type 2 diabetes and glucose toxicity (Brownlee et al. 1988, Rossetti et al. 1995, Hebert et al. 1996). Rate-limiting enzymes in the HBP are glutamine: fructose-6-phosphate amidotransferase (GFAT), which catalyzes the formation of glucosamine-6-phosphate from fructose-6-phosphate and glutamine, and O-glucosamine acetyl transferase, which adds a UDP-acetylglucosamine group to a target protein and is overexpressed in pancreas. Adipocytes (Considine et al. 2000), fibroblasts, and rodents (Brownlee et al. 1988, Shankar et al. 1998, Veerababu et al. 2000, Einstein et al. 2008) exposed to glucosamine, which directly enters and stimulates the HBP, develop insulin resistance. In addition, HBP activation induces defects in insulin production and secretion by attenuating the activity of glucokinase in $\beta$-cells (Balkan \& Dunning 1994, Shankar et al. 1998, Yoshikawa et al. 2002). Similar to animals exposed to glucosamine, transgenic animals overexpressing GFAT either in skeletal muscle, fat, or in liver also develop insulin resistance (Hebert et al. 1996, Veerababu et al. 2000). Less is known about the effects of HBP in humans. Although GFAT levels have been shown to correlate inversely with glucose disposal rate (Daniels et al. 1996) and fasting glycemia (Monauni et al. 2000) in humans, this issue remains controversial, as others have found that HBP has no impact on insulin sensitivity (Pouwels et al. 2001). In contrast, stimulation of HBP by glucosamine was demonstrated to cause apoptosis in both rodent (Konrad et al. 2001, Okuyama \& Yachi 2001, Anello et al. 2004) and human (D'Alessandris et al. 2004) pancreatic $\beta$-cells, despite the up-regulation of cell survival factors such as MAFA (Vanderford et al. 2007).

SIRT1 is a deacetylase enzyme mostly located in the nucleus but also found in the cytoplasm under certain 
conditions (Tanno et al. 2007). Its NAD-dependent activity suggests that this protein may sense the metabolic state of cells and modulate gene expression accordingly. SIRT1 was shown to impact on cell survival through physical binding with p53, HSF1, Hif-2 $\alpha$, FOXO, and Ku70 (Dioum et al. 2009, Westerheide et al. 2009, Gagarina et al. 2010) and reviewed in Yamamoto et al. (2007). Importantly, SIRT1 and its yeast homolog SIR2 appear to be very sensitive to changes in cellular glucose content such as those occurring upon caloric restriction (Lin et al. 2000, Cohen et al. 2004, Nisoli et al. 2005, Civitarese et al. 2007, Chen et al. 2008, Kanfi et al. 2008, Nedachi et al. 2008). In cultured pancreatic $\beta$-cells, overexpression of Sirt1 was shown to protect against cytokine toxicity (Lee et al. 2009). Moreover, glucosamine treatment in the hepatic HepG2 cell line acutely reduces SIRT1 protein levels (Sun et al. 2007). In this context, we postulated the hypothesis that HBP stimulation could induce $\beta$-cell death through a reduction in SIRT1 level and/or activity.

\section{Materials and Methods}

\section{Cell culture and treatment}

Mouse Nit-1 and rat Rin-m5F cell lines were bought from ATCC (Rockville, MD, USA). Mouse Min6 cells were a kind gift from Dr André Marette (Université Laval, Canada). Nit-1 and Rin-m5F cells were cultured in Ham's F12K medium (Sigma-Aldrich) containing $5 \mathrm{mM}$ glucose added with $1.5 \mathrm{~g} / 1$ sodium bicarbonate and $10 \%$ heat-inactivated dialyzed fetal bovine serum (FBS). Min6 cells were cultured in DMEM high glucose supplemented with 15\% FBS, $5 \mu \mathrm{l} / 1$ $\beta$-mercaptoethanol, and $10 \mathrm{mM}$ HEPES. Cells were cultured at $37{ }^{\circ} \mathrm{C}$ in a humidified incubator at $5 \% \mathrm{CO}_{2}$. Experiments were typically performed at $80 \%$ confluence. Following the treatments, cells were harvested, centrifuged in collection tubes for mRNA and protein extractions, and were frozen at $-20{ }^{\circ} \mathrm{C}$ until subsequent analysis. Viral production and infection were performed exactly as previously described (Picard et al. 2004). Infected cells were kept in a medium containing puromycin throughout the study.

\section{Measurement of cell death}

Cell death and apoptosis were quantified using three complementary approaches. Cells were harvested by treatment with a cell dissociation buffer (an enzyme free Hank's based solution; Gibco). Dead cells were counted based on dye exclusion after trypan blue staining in a hemacytometer. Annexin $\mathrm{V}$ assays were used to measure cell death through reorganization of phosphatidylserine in cell membrane. Briefly, cells were resuspended in annexin binding buffer (10 $\mathrm{mM}$ HEPES, $\mathrm{pH}=7 \cdot 4,140 \mathrm{mM} \mathrm{NaCl}$, and $5 \mathrm{mM}$ $\mathrm{CaCl}_{2}$ ) containing annexin V-FITC (Roche Diagnostic) and Hoechst 33258 (Sigma-Aldrich) for $10 \mathrm{~min}$ in the dark. Cells were washed three times with ice-cold PBS, plated on slides, and allowed to dry. Cells were then coverslipped with MOWIOL 4-88 mounting medium (Calbiochem, Gibbstown, NJ, USA). TUNEL assays were conducted following the manufacturer's instructions (Roche Diagnostic). For TUNEL assays, floating cells were not taken into account, which at least underestimated apoptosis ratios. Slides were analyzed by microscopy (IX-81 by Olympus, Markham, ON, Canada). Pictures were taken using an Evolution QEi camera and image Pro Plus 6.0 software (Media Cybernetics, Bethesda, MD, USA).

\section{$R N A$ analysis and real-time quantitative $R T-P C R$}

Total RNA from cultured cells was extracted according to the standard protocol provided with RNAspin mini isolation kit (GE Healthcare, Baie d'Urfe, QC, Canada) and quantified by Experion automated electrophoresis system (Bio-Rad). A reverse transcription step was carried on $1 \mu \mathrm{g}$ purified RNA by using oligo dT and SuperScript II reverse transcriptase (Invitrogen) at $42{ }^{\circ} \mathrm{C}$ for $1 \mathrm{~h}$. Relative quantification of cDNA amplification was performed on reactions containing $40 \mathrm{ng}$ cDNA, $0 \cdot 25 \mu \mathrm{M}$ sense and antisense primers, $2 \mu \mathrm{M}$ $\mathrm{MgCl}_{2}$, and SYBR Green JumpStart Taq ReadyMix without $\mathrm{MgCl}_{2}$ (Sigma-Aldrich) in a final volume of $20 \mu \mathrm{l}$ for each reaction. Amplification and detection of specific products were obtained with the Rotor-Gene RG-3000 (Corbett Research, Concorde, NSW, Australia) (primer sequences and $\mathrm{qPCR}$ protocols available on request). Relative level of gene expression was determined via a standard curve composed of a cDNA mix from all groups. PCR data were normalized over HPRT expression (hypoxanthine-guanine phosphoribosyltransferase) used as a housekeeping gene.

\section{Protein extraction and western blot analysis}

Cells were scraped in lysis buffer A (10 mM HEPES, $\mathrm{pH}=7 \cdot 9$, $10 \mathrm{mM} \mathrm{KCl}, 100 \mu \mathrm{M}$ EDTA, $100 \mu \mathrm{M}$ EGTA, $1 \mathrm{M}$ dithiothreitol (DTT) (1:1000), and Protease Inhibitor Cocktail (Sigma-Aldrich) (1:1000)) and combined with floating cells fraction. NP40 was added to each sample before vigorous mixing and nucleus recovery through centrifugation. Then, nuclei were resuspended in lysis buffer $\mathrm{C}$ (20 $\mathrm{mM}$ HEPES, $\mathrm{pH}=7 \cdot 9$, $400 \mathrm{mM} \mathrm{NaCl}, 1 \mathrm{mM}$ EDTA, $1 \mathrm{mM}$ EGTA, $1 \mathrm{M}$ DTT (1:1000), and Protease Inhibitor Cocktail (1:1000)) and mixed. Proteins were recovered in the supernatant and dosed on a u.v. plate reader by DC Protein Assay (Bio-Rad). A total of $20 \mu \mathrm{g}$ of each sample were resolved by SDS-PAGE and transferred to PVDF membranes. After a $2 \mathrm{~h}$ transfer, membranes were blocked in a 5\% milk (in BSA-1X) for $35 \mathrm{~min}$. Then, membranes were incubated with different primary antibodies at $4{ }^{\circ} \mathrm{C}$ overnight against Bax (1:500) (Santa Cruz sc-526, Santa Cruz, CA, USA), c-Jun (1:700) (Santa Cruz sc-45), E2F1 (1:700) (Santa Cruz sc-193), p53 (1:700) (Santa Cruz sc-6243), p65-NFKB (1:700) (Santa Cruz sc-372), Sirt1 (1:2000) (Upstate 07-131), ubiquitin (1:700) (Santa Cruz sc-9133), and glycosylated proteins (Affinity BioReagents MA1-072). The measure of actin (1:25 000) 
(Upstate MAB1501) was used as a loading control. The next day, membranes were rinsed four times in wash buffer (TBS $1 \times$ with Tween 20 and NP40) before incubation for $1 \mathrm{~h}$ at $4{ }^{\circ} \mathrm{C}$ with respective $\mathrm{HRP}$-conjugated secondary antibodies (1:5000) (Amersham). Membranes were washed four times in wash buffer, and tagged proteins were visualized by ECL system (GE Healthcare).

\section{Immunofluorescence}

Cells were plated on coverslips and treated with $5 \mathrm{mM}$ glucosamine for 1,5 , and $24 \mathrm{~h}$. Cells were fixed in methanol at $4{ }^{\circ} \mathrm{C}$ for $10 \mathrm{~min}$. After three washes with ice-cold PBS, non-specific binding sites were saturated with 1\% BSA-PBS for $10 \mathrm{~min}$ at room temperature. Then, cells were incubated with Sirt1 antibody $(1: 25)$ in $1 \%$ BSA-PBS. Secondary antibodies used were FITC-conjugated affinipure goat anti-rabbit IgG (1:1000) (Jackson ImmunoResearch, West Grove, PA, USA) with nuclear staining with Hoechst 33258 $(1: 1000)$ in 1\% BSA-PBS. Coverslips were mounted on slides using Vectashield mounting medium (VectorLabs, Burlington, ON, Canada) and analyzed by microscopy (IX-81 by Olympus). Pictures were acquired using an Evolution QEi camera and image Pro Plus 6.0 software (Media Cybernetics).

\section{Chromatin immunoprecipitation}

Nit-1 cells were cross-linked with 1\% paraformaldehyde at room temperature after $6,12,18$, or $24 \mathrm{~h}$ of $5 \mathrm{mM}$ glucosamine treatment. Cells were washed three times with ice-cold PBS and scraped in ChIP lysis buffer $(50 \mathrm{mM}$ HEPES, $\mathrm{pH}=7 \cdot 5,140 \mathrm{mM} \mathrm{NaCl}, 1 \%(\mathrm{v} / \mathrm{v})$ Triton $\mathrm{X}-100$, and Protease Inhibitor Cocktail 1:1000). Cells were sonicated to shear DNA by repeating seven cycles of sonication: $9 \mathrm{~s}$ at $30 \%$ of the maximum amplitude (Sonifier Cell Disrupter 185, Branson, Danbury, CT, USA) with 1 min pauses of $10 \mathrm{~s}$ on dry ice followed by $50 \mathrm{~s}$ on ice. After taking fractions of sheared DNA for inputs, samples were pre-cleared with $50 \mu$ l of Protein A Sepharose Fast Flow (GE Healthcare) beads and $20 \mu \mathrm{g}$ salmon sperm ssDNA (Invitrogen) for $1 \mathrm{~h}$ at $4{ }^{\circ} \mathrm{C}$. Supernatants were then split to incubate with $50 \mu \mathrm{l}$ beads, $20 \mu \mathrm{g}$ ssDNA, and $4 \mu \mathrm{g}$ rabbit IgG (Santa-Cruz, sc-2027) as a negative control, and with $4 \mu \mathrm{g}$ E2F1 or $2 \mu \mathrm{g}$ Sirt1 antibodies for ChIP assay and were rocked overnight at $4{ }^{\circ} \mathrm{C}$. On the next day, samples were washed twice with ChIP lysis buffer, one time with ChIP lysis buffer high salt (50 mM HEPES, $\mathrm{pH}=7 \cdot 5,0 \cdot 5 \mathrm{M}$ $\mathrm{NaCl}, 1 \%(\mathrm{v} / \mathrm{v})$ Triton X-100, and Protease Inhibitor Cocktail 1:1000), twice with wash buffer $(10 \mathrm{mM}$ Tris,
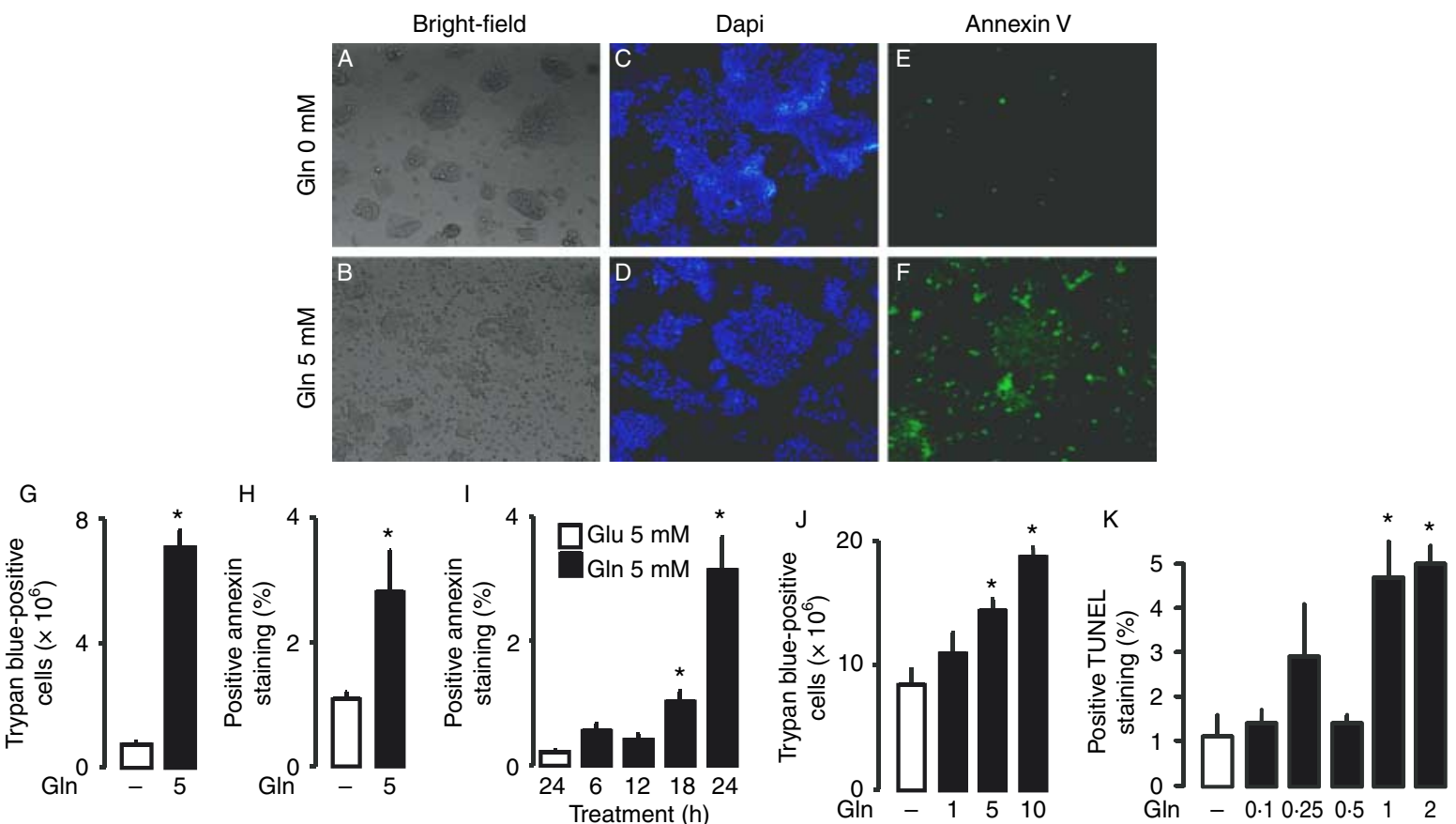

Figure 1 Glucosamine treatment dose- and time dependently triggers $\beta$-cell death. Cells were treated with or without glucosamine at the indicated time and doses. Bright-field pictures ( $A$ and $B$ ), nucleus staining (Hoechst) ( $C$ and $D)$, and immunofluorescent annexin $V$ staining ( $\mathrm{E}$ and $\mathrm{F}$ ) of Nit-1 cells taken $24 \mathrm{~h}$ after glucosamine treatment ( $24 \mathrm{~h})$. Loss of $\beta$-cells was then scored by cell count of trypan blue (G) or annexin staining $(\mathrm{H})$ after correction for total cell number. (I) Time course of positive annexin staining in Nit-1 cells after 5 mM glucosamine treatment. (J) Dose-response of cell death in Rin-m5F cells treated with glucosamine for $24 \mathrm{~h}$. (K) Dose-response of cell death in Nit-1 cells treated with glucosamine for $48 \mathrm{~h}$. TUNEL assays (representative left panels) were done at the end of the incubation period. Data shown were obtained from at least three independent experiments done in duplicate. Bars are mean \pm S.E.M. * indicates a significant effect $(P<0 \cdot 05)$ compared to the control group (white bars). Full colour version of this figure available via http://dx.doi.org/10.1677/JOE-10-0243. 


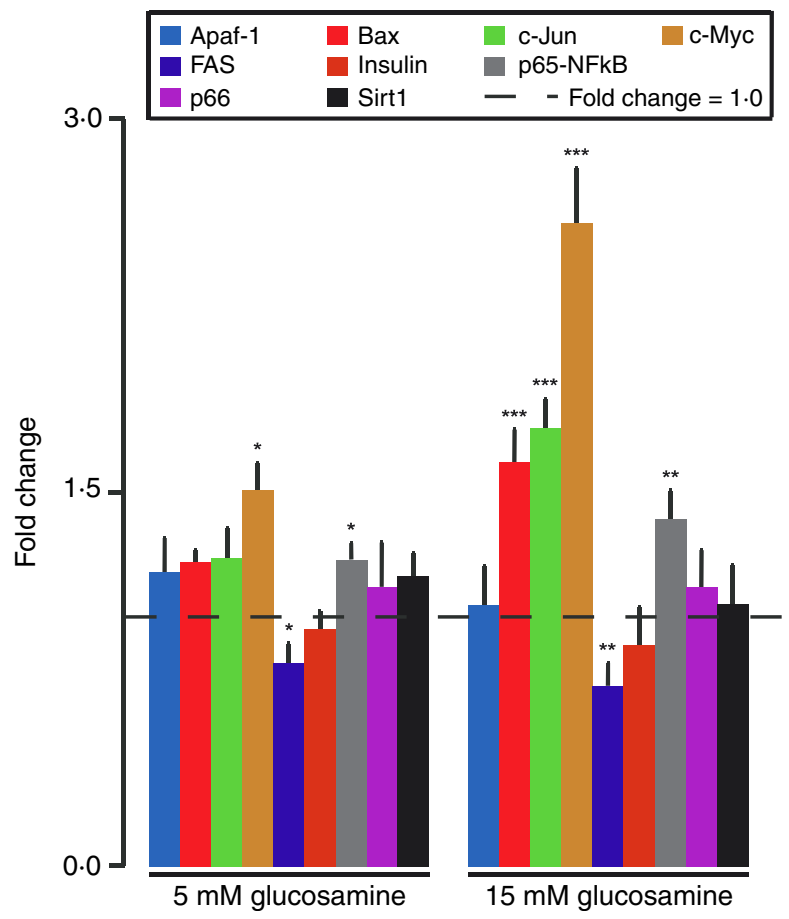

Figure 2 Glucosamine triggers an apoptotic transcriptional program in Nit-1 cells after $24 \mathrm{~h}$ of treatment. Quantitative real-time PCR results were corrected for mRNA levels of GAPDH as a housekeeping gene. Data shown were obtained from three independent experiments done in duplicate. Bars represent fold change compared to the control condition (dotted line). Asterisks indicate a statistical difference from the control group $\left({ }^{*} P<0 \cdot 05 ;{ }^{* *} P \leq 0 \cdot 01 ;{ }^{* * *} P \leq 0 \cdot 0001\right)$. Full colour version of this figure available via http://dx.doi.org/10.1677/ JOE-10-0243.

$\mathrm{pH}=8 \cdot 0,250 \mathrm{mM} \mathrm{LiCl}, 0 \cdot 5 \%(\mathrm{v} / \mathrm{v}) \mathrm{NP} 40$, and $1 \mathrm{mM}$ EDTA), and twice with TE $(10 \mathrm{mM}$ Tris, $\mathrm{pH}=8 \cdot 0$, and $10 \mathrm{mM}$ EDTA). Beads were eluted (10 mM Tris, $\mathrm{pH}=8 \cdot 0$, $1 \%(\mathrm{v} / \mathrm{v})$ SDS, and $10 \mathrm{mM}$ EDTA) with two rounds of heating at $65^{\circ} \mathrm{C}$ separated by vortexing. Combined supernatants and inputs were heated at $65^{\circ} \mathrm{C}$ overnight. The next day, DNA was purified using PCR Purification Kit (Qiagen) followed by PCR on the c-myc promoter with specific primers (forward, 5'-GCGGGGGCTCCTAGATAACTC- $3^{\prime}$; reverse, $5^{\prime}$-CGGCTCCGGGGTGTAAAC-3') or on the Hsp70 promoter (forward, 5'-GAACCCACAACTCCGATTACTCA-3'; reverse, 5'-TCTTGTCTTCGCTTGTCTCTGGAT-3'). Amplification results were obtained by migration on $1 \% \mathrm{EtBr}$ agarose gel.

\section{Statistical analysis}

Data are presented as means \pm s.E.M. The main and interactive effects were analyzed by ANOVA. When justified by ANOVA, differences between individual group means were analyzed by Fisher's PLSD test. Differences were considered statistically significant at $P<0 \cdot 05$.

\section{Results}

HBP stimulation induces apoptosis in $\beta$-cells

HBP stimulation by glucosamine treatment induced a large increase in the number of floating cells resulting from disorganization of $\beta$-cell colonies (Fig. 1A and B). Cells treated with glucosamine lost almost every ultrastructural feature such as beta granules and well-developed rough
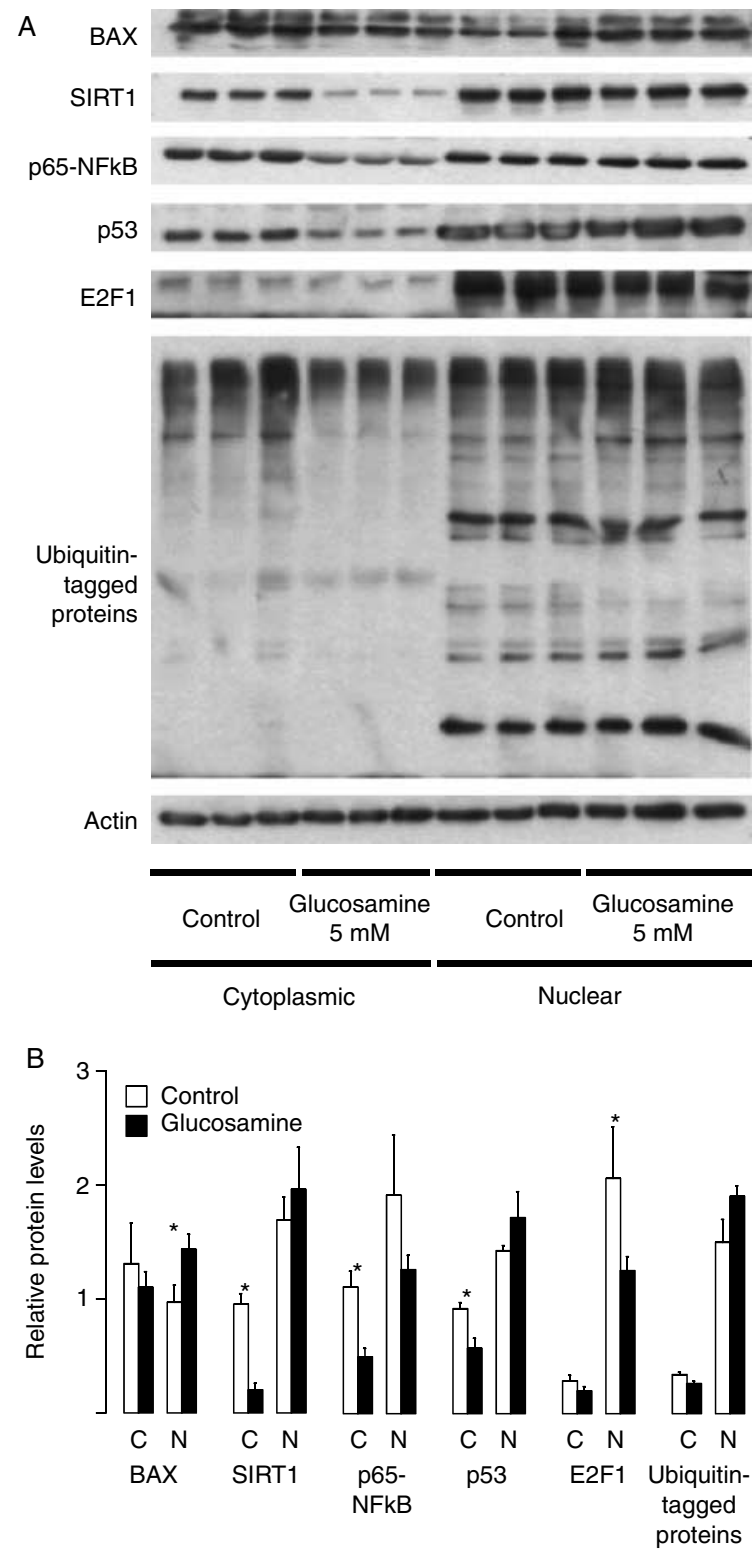

Figure 3 Effects of glucosamine treatment on the protein cellular location and levels in Nit-1 cells harvested after 24 h of glucosamine treatment $(\mathrm{A})$. Actin levels are shown as loading controls. Each lane from both groups represents an independent experiment. (B) Quantification of the protein levels shown in (A) relative to those of actin. ${ }^{*} P<0.05$ compared to the vehicle treatment. 
endoplasmic reticulum. Cell death was also apparent following nucleus staining (Fig. 1C and D). These findings were confirmed by annexin $\mathrm{V}$ staining (Fig. 1E-H). The impact of glucosamine treatment was not due to osmotic or $\mathrm{pH}$ modification, as control solutions with mannitol or $\mathrm{pH}$ comparable to that of glucosamine did not result in any change in cell death (data not shown). Statistical analysis of cell death ratio indicated that $5 \mathrm{mM}$ glucosamine stimulated cell death within 18-24 h of treatment (Fig. 1I). The significant impact of glucosamine was also observed in rat Rin-m5F $\beta$-cells (Fig. 1J), indicating that the effect of HBP stimulation on cell death is not species-specific. Further tests using highly sensitive TUNEL assays indicated that a $48 \mathrm{~h}$ treatment with a lower dose of $1 \mathrm{mM}$ glucosamine also increased cell death (Fig. 1K). These findings demonstrate that HBP stimulation even by a low dose of glucosamine induces $\beta$-cell apoptosis.

\section{HBP stimulation modulates the levels and cellular location of pro-apoptotic factors}

Previous studies suggested that glucosamine treatment of rat $\beta$-cells results in reduced insulin synthesis (Andreozzi et al. 2004), and in the inactivation of the IRS1/PI3K pathway, leading to increased c-Jun/JNK and a down-regulation of FOXO1 activity (Andreozzi et al. 2004, D'Alessandris et al. 2004). In the present study, further analysis of apoptotic pathways by real-time quantitative PCR revealed that glucosamine treatment dose dependently stimulated the mRNA expression of Myc, Bax, Jun, and the p65 unit of NFKB (Fig. 2). In contrast, fatty acid synthase (FAS) expression levels were significantly down-regulated by glucosamine treatment. However, no change in glucokinase mRNA levels was found. Insulin, Apaf-1, and Sirt 1 mRNA levels also remained unchanged after incubation with glucosamine (Fig. 2).

Determination of protein cellular location and expression levels confirmed the increase in BAX levels upon glucosamine treatment, which was mainly observed in the nucleus (Fig. 3). Overall, ubiquitination of proteins did not change upon treatment (Fig. 3). Cytoplasmic protein levels of p65$\mathrm{NFkB}$ and p53 were reduced (Fig. 3). Interestingly, E2F1 levels were slightly diminished in the nucleus $24 \mathrm{~h}$ after glucosamine treatment (Fig. 3).

\section{HBP affects SIRT1 level and activity}

Consistent with previous findings in hepatic HepG2 cells (Sun et al. 2007), western blotting revealed a robust decline in the cytoplasmic fraction of SIRT1 $24 \mathrm{~h}$ after incubation with glucosamine (Fig. 3). Given the possibility that SIRT1 serves as a node interacting with and inhibiting pro-apoptotic factors such as E2F1 and p53 while
A

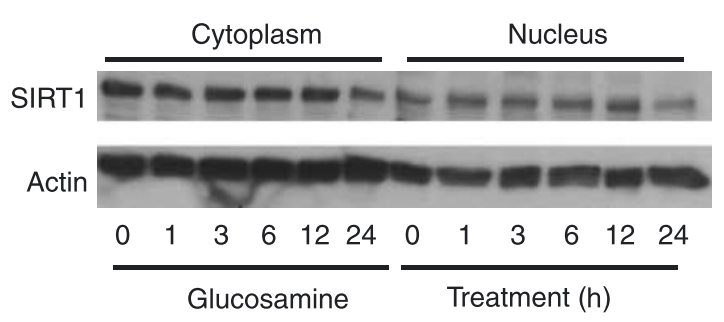

C
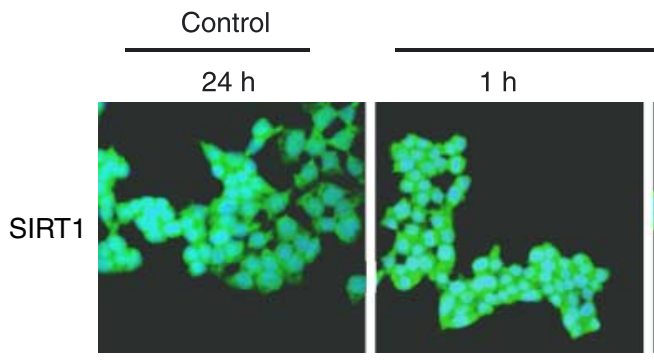

B

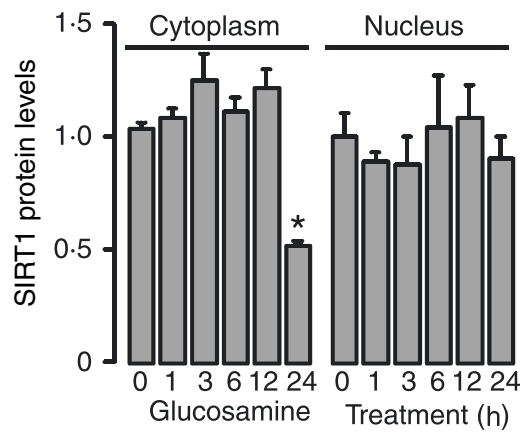

Glucosamine $5 \mathrm{mM}$

$5 \mathrm{~h}$

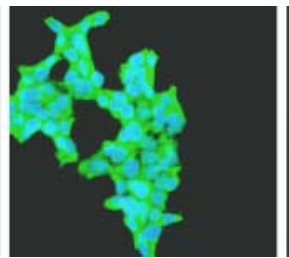

$24 \mathrm{~h}$

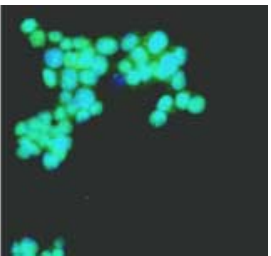

Figure 4 Stimulation of HBP by glucosamine alters SIRT1 protein levels and location. (A) Western blot of SIRT1 protein at 0-24 h after glucosamine exposure in Nit-1 cells. (B) Quantitative analysis of the changes in SIRT1 protein levels upon glucosamine treatment $(n=3)$. Signals for SIRT1 were divided by those for actin to account for loading. * indicates $P<0 \cdot 0001$. (C) Time course showing localization of SIRT1 (green) using immunofluorescence in Nit-1 cells treated with $5 \mathrm{mM}$ glucosamine. Cell nuclei are shown in blue (Hoechst). Data shown are representative of three independent experiments done in duplicate. Full colour version of this figure available via http://dx.doi.org/10.1677/JOE-10-0243. 
A

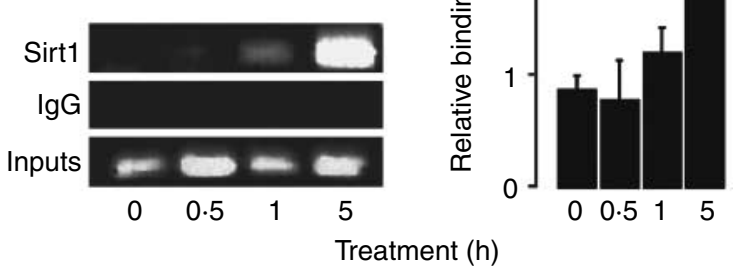

B

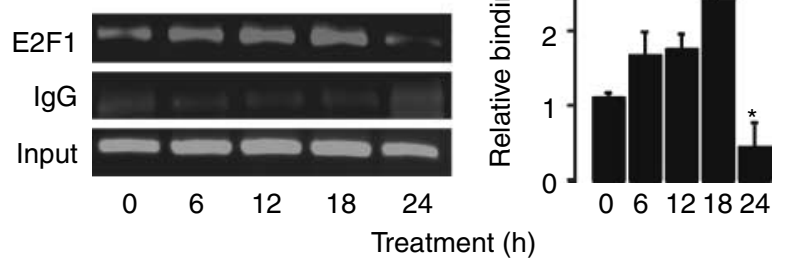

Figure 5 Time-dependent transactivation of Hsp70 and Myc promoters by HBP stimulation. (A) ChIP assay on Sirt1 and IgC (control)-immunoprecipitated DNA from Nit-1 cells treated with $5 \mathrm{mM}$ glucosamine for up to $5 \mathrm{~h}$. A sequence containing the Hsp70 promoter was amplified by specific primers. (B) ChIP assay on E2F1 and IgG (control)-immunoprecipitated DNA from Nit-1 cells treated with $5 \mathrm{mM}$ glucosamine for $6-24 \mathrm{~h}$. A sequence containing E2F1 response elements from the Myc promoter was amplified by specific primers. For both $A$ and $B$, quantification of the binding signals is shown on the right panels. Data shown are representative of three independent experiments. ${ }^{*} P<0 \cdot 05$ compared to $0 \mathrm{~h}$ of treatment.

stimulating anti-apoptotic factors such as HSF1, a timecourse study was performed to document the decrease in SIRT1 protein level upon glucosamine treatment. The reduction $(58 \%, P<0 \cdot 0001)$ was noticeable only $24 \mathrm{~h}$ after the beginning of the incubation period (Fig. 4A and B). At that time point, most of SIRT1 protein was observed in the nucleus (Fig. 4C). This diminution in SIRT1 protein expression while mRNA levels remained constant suggests that SIRT1 protein degradation might be increased by HBP stimulation.

To test the effect of this phenomenon on Sirt1 transcriptional activity, ChIP assays were first performed on the promoter of the heat shock protein 70 (Hsp70), which has a protective, anti-apoptotic effect against stress (Daugaard et al. 2007). SIRT1 binding to the Hsp70 promoter was induced within $1 \mathrm{~h}$ by glucosamine treatment and remained high $5 \mathrm{~h}$ after HBP stimulation (Fig. 5A). Then, as SIRT1 protein levels are decreasing as a function of glucosamine treatment (Fig. 4), possibly because of progressing changes in protein conformation, we postulated that its inhibitory activity on E2F1 would also diminish, thus allowing E2F1 to stimulate pro-apoptotic gene transcription. Consistent with this concept, binding of $\mathrm{E} 2 \mathrm{~F} 1$ on the Myc promoter, as evidenced by ChIP, was increased from 6 to $18 \mathrm{~h}$ of HBP stimulation, but was greatly reduced at $24 \mathrm{~h}$ (Fig. 5B).
Genetic manipulation of SIRT1 levels modulates apoptotic susceptibility to $\mathrm{HBP}$

To confirm that reduced SIRT1 contributes to HBP-induced apoptosis, virus-mediated, specific Sirt1 knockdown (T1 KD) was performed in Nit-1 cells, which resulted in a $60 \%$ decrease in its protein level (Fig. 6A). In normal conditions, death ratios were similar between control and T1 KD cells (Fig. 6B). In contrast, compared to control cells, T1 KD cells were significantly more susceptible to apoptosis when incubated with glucosamine (Fig. 6B). These findings indicate that reduction of SIRT1 exacerbates HBP-induced cell death in Nit-1 $\beta$-cells.

To further validate this observation, levels of the Sirt1 gene were increased ( $\mathrm{pBabe-Sirt1)}$ or reduced (pSuperSirt1-RNAi) in mouse Min6 cells by retroviral infection. On the one hand, overexpression of Sirt1 resulted in a protection against glucosamine-induced cell death as quantified by trypan blue (Fig. 7A) and annexin (Fig. 7B) staining. On the other hand, cells with down-regulation of Sirt1 levels showed increased basal and glucosamine-stimulated apoptosis (Fig. 7A and B). These results confirmed that modulation of SIRT1 levels impacts on HBPinduced apoptosis.

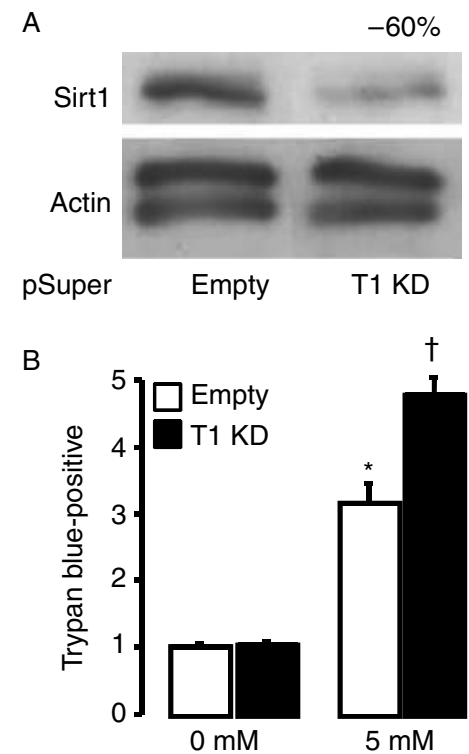

Figure 6 Reduction in Sirt1 levels exacerbates HBP-induced apoptosis in Nit-1 $\beta$-cells. (A) SIRT1 protein levels in Nit-1 cells infected with viruses produced through an empty (pSuper) plasmid, or with a sequence specifically targeting Sirt1 (T1 KD) (Picard et al. 2004). (B) Cell death in infected cells incubated or not with $5 \mathrm{mM}$ glucosamine for $12 \mathrm{~h}$. Results are mean \pm s.E.M. of three independent experiments done in triplicate. ${ }^{*}$ indicates significant effect of glucosamine; + indicates significant difference with empty virus. 

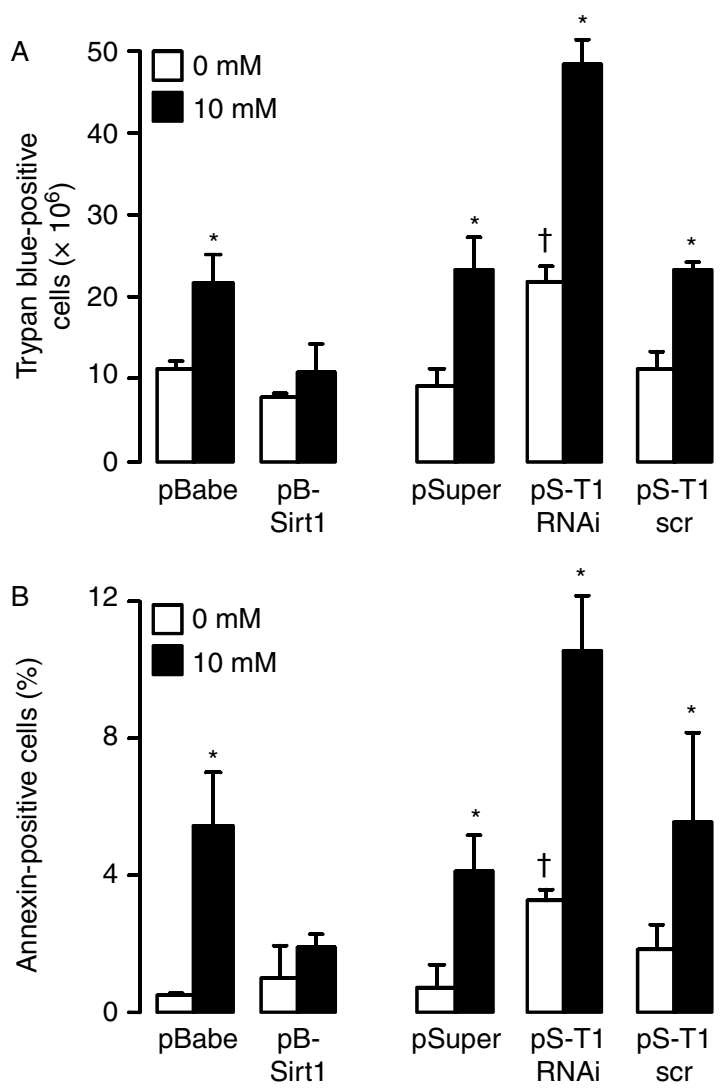

Figure 7 Overexpression of Sirt1 protects against HBP-induced apoptosis in Min6 $\beta$-cells. Overexpression (pBabe-Sirt1) or downregulation (pSuper-Sirt1-RNAi) of Sirt1 was achieved by retroviral infection. After at least 10 days of antibiotic selection, Min6 cells were incubated with glucosamine. Trypan blue- (A) and annexin(B) positive cells were quantified $48 \mathrm{~h}$ after. $*$ indicates a significant effect of glucosamine $(P<0 \cdot 05)$. + indicates a significant effect of the virus compared to the control pSuper group $(P<0 \cdot 05)$. Results are mean \pm S.E.M. of two independent experiments done in triplicate. pS-Sirt1-scr represents the same plasmid as pS-Sirt1-RNAi except that the RNAi sequence was scrambled as a negative control.

\section{Discussion}

It has previously been shown that stimulation of the HBP results in apoptosis in several models of pancreatic $\beta$-cells. The findings of the present study indicate that this pathway can modify SIRT1 protein levels and location, resulting in reduced activity and a concomitant transactivation of pro-apoptotic target genes such as $M \gamma c$.

The present study confirms in three different cell lines that HBP stimulation by glucosamine triggers $\beta$-cell apoptosis and subsequent cell death at a dose even lower than that used in previous reports (Konrad et al. 2001, Okuyama \& Yachi 2001, Anello et al. 2004, D'Alessandris et al. 2004). On the one hand, consistent with strong annexin staining, $M \gamma c$ and $N F K B$ transactivation, morphologic differences observed after glucosamine exposure as well as modified expression patterns of genes such as Fas showed that cell metabolism was robustly altered, likely in a time-dependent manner. On the other hand, the mRNA expression of some, but not other, pro-apoptotic factors was not significantly changed upon $5 \mathrm{mM}$ glucosamine treatment, suggesting activation of specific pathways implicated in apoptosis. These could be linked to altered mitochondrial function (Balestrieri et al. 2008) and production of reactive oxygen species, as SIRT1 controls the expression of UCP2 in pancreatic $\beta$-cells (Bordone et al. 2005, Moynihan et al. 2005) and consequently insulin secretion.

Our findings demonstrate that modulation of SIRT1 levels robustly interferes with HBP-induced $\beta$-cell apoptosis. The glucosamine-stimulated reduction of SIRT1 protein would likely affect many pathways involved in cell cycle and apoptosis. Our data suggest that SIRT1 can initially protect against HBP-induced metabolic stress by activating the Hsp70 promoter (Fig. 5A), but that, in the longer term, loss of SIRT1 function enables pro-apoptotic factors. Previous data indicate that SIRT1 can inhibit E2F1 activity through direct physical interaction (Wang et al. 2006). From our present findings, it could be postulated that reduced SIRT1 levels could diminish its docking to E2F1, which could then stimulate the binding of E2F1 to the MYC promoter (Fig. 5B), triggering transactivation of the gene and induction of apoptosis. Reduced E2F1 DNA binding at $24 \mathrm{~h}$ might be due to a slightly reduced protein level (Fig. 3) or to the fact that other pro-apoptotic mechanisms take place at this time point. However, to date, attempts to pinpoint one exclusive specific mechanism (e.g. via altered SIRT1 docking to E2F1, FOXO, or HSF1) have not been conclusive, leading to the speculation that SIRT1 may act through multiple networks.

Several studies have reported increased SIRT1 protein levels (Balestrieri et al. 2008, Kanfi et al. 2008, Nedachi et al. 2008) and nuclear accumulation (Nedachi et al. 2008) under conditions of low glucose concentrations. In line with this, a report showed that glucosamine reduced SIRT1 protein expression in HepG2 cells (Sun et al. 2007). These observations suggest that stimulation of HBP by glucosamine affects SIRT1 stability, a concept supported by our findings that glucosamine reduces SIRT1 protein but not mRNA levels (Figs 2,-4). Phosphorylation of SIRT1 has been hypothesized to play a significant role in its deacetylase activity (Beausoleil et al. 2004), and glycosylation was shown to affect the same protein motifs as phosphorylation (Zachara \& Hart 2004). Transcription factors and other protein components of the nucleus can become glycosylated, which triggers rapid changes in affinity, specificity, and stability of components in protein complexes. For example, this applies in $\beta$-cells to PDX-1 (Gao et al. 2003, Akimoto et al. 2007) and H6451sp60, which detaches from BAX upon HBP stimulation and triggers $\mathrm{BAX}$ translocation to the mitochondria (Kim et al. 2006). The balance between phosphorylation and glycosylation, in association with the reported sumoylation modification of SIRT1 (Yang et al. 2007), could thus represent a fine-tuning regulatory mechanism of SIRT1 activity. Moreover, prolonged glycosylation was previously 
shown to modulate protein ubiquitination (Guinez et al. 2008), a mechanism that could have contributed, in the present study, to the decrease in SIRT1 observed after $24 \mathrm{~h}$ of glucosamine treatment. Given the proposed links between SIRT1 and longevity (Bordone et al. 2007, Guarente 2008) and the increase in HBP activity shown in aged rats (Einstein et al. 2008), more studies are required to better analyze how HBP stimulation controls SIRT1 protein status.

While confirming that stimulation of the HBP triggers $\beta$-cell apoptosis, our present findings reveal that this effect is associated with robust changes in SIRT1 protein levels, which leads to impaired activity, allowing transactivation of pro-apoptotic genes. The relevance of this novel mechanism remains, however, to be demonstrated in vivo or using isolated islets. In addition, compared to that of other established HBP-induced pro-apoptotic pathways, the relative contribution of this molecular mechanism to overall cell death is still to be clarified. Finally, the findings described herein suggest that post-translational modifications of SIRT1 might play an important role in the responses of $\beta$-cell to metabolic stresses.

\section{Declaration of interest}

The authors declare that there is no conflict of interest that could be perceived as prejudicing the impartiality of the research reported.

\section{Funding}

M L-L was a recipient of FER, FRSQ, and IRSC studentships. G D is a recipient of FER and CRIUPQ studentships. F P holds a FRSQ Junior 2 Investigator Award. This work was supported by operating grants from the CIHR (MOP-66967 and CCI-85677) and Diabète Québec.

\section{Author contribution statement}

M L-L designed the experiments, performed experiments shown in Figs 1, 3, $4 \mathrm{~A}$ and $\mathrm{B}, 5,6$, and 7 , analyzed the data, and wrote the manuscript. G D performed the experiments shown in Figs 1, 4C, and 7, and analyzed the data. F P initiated the study, designed the experiments, analyzed the data, and wrote the manuscript.

\section{Acknowledgements}

We would like to thank Yves Deshaies for critical reading of the manuscript

\section{References}

Akimoto Y, Hart GW, Wells L, Vosseller K, Yamamoto K, Munetomo E, Ohara-Imaizumi M, Nishiwaki C, Nagamatsu S, Hirano H et al. 2007 Elevation of the post-translational modification of proteins by $\mathrm{O}$-linked $\mathrm{N}$-acetylglucosamine leads to deterioration of the glucose-stimulated insulin secretion in the pancreas of diabetic Goto-Kakizaki rats. Glycobiology 17 127-140. (doi:10.1093/glycob/cwl067)

Andreozzi F, D’Alessandris C, Federici M, Laratta E, Del Guerra S, Del Prato S, Marchetti P, Lauro R, Perticone F \& Sesti G 2004 Activation of the hexosamine pathway leads to phosphorylation of insulin receptor substrate-1 on Ser307 and Ser612 and impairs the phosphatidylinositol

3-kinase/Akt/mammalian target of rapamycin insulin biosynthetic pathway in RIN pancreatic beta-cells. Endocrinology 145 2845-2857. (doi:10.1210/ en.2003-0939)

Anello M, Spampinato D, Piro S, Purrello F \& Rabuazzo AM 2004 Glucosamine-induced alterations of mitochondrial function in pancreatic beta-cells: possible role of protein glycosylation. American Journal of Physiology. Endocrinology and Metabolism 287 E602-E608. (doi:10.1152/ ajpendo.00320.2003)

Balestrieri ML, Rienzo M, Felice F, Rossiello R, Grimaldi V, Milone L, Casamassimi A, Servillo L, Farzati B, Giovane A et al. 2008 High glucose downregulates endothelial progenitor cell number via SIRT1. Biochimica et Biophysica Acta 1784 936-945. (doi:10.1016/j.bbapap.2008.03.004)

Balkan B \& Dunning BE 1994 Glucosamine inhibits glucokinase in vitro and produces a glucose-specific impairment of in vivo insulin secretion in rats. Diabetes 43 1173-1179. (doi:10.2337/diabetes.43.10.1173)

Beausoleil SA, Jedrychowski M, Schwartz D, Elias JE, Villen J, Li J, Cohn MA, Cantley LC \& Gygi SP 2004 Large-scale characterization of HeLa cell nuclear phosphoproteins. PNAS 101 12130-12135. (doi:10.1073/pnas. 0404720101)

Bordone L, Motta MC, Picard F, Robinson A, Jhala US, Apfeld J, McDonagh T, Lemieux M, McBurney M, Szilvasi A et al. 2005 Sirt1 regulates insulin secretion by repressing UCP2 in pancreatic beta cells. PLoS Biology 4 e31. (doi:10.1371/journal.pbio.0040031)

Bordone L, Cohen D, Robinson A, Motta MC, van Veen E, Czopik A, Steele AD, Crowe H, Marmor S, Luo J et al. 2007 SIRT1 transgenic mice show phenotypes resembling calorie restriction. Aging Cell 6 759-767. (doi:10. 1111/j.1474-9726.2007.00335.x)

Brownlee M, Cerami A \& Vlassara H 1988 Advanced glycosylation end products in tissue and the biochemical basis of diabetic complications. New England Journal of Medicine 318 1315-1321. (doi:10.1056/ NEJM198805193182007)

Chen D, Bruno J, Easlon E, Lin SJ, Cheng HL, Alt FW \& Guarente L 2008 Tissue-specific regulation of SIRT1 by calorie restriction. Genes and Development 22 1753-1757. (doi:10.1101/gad.1650608)

Civitarese AE, Carling S, Heilbronn LK, Hulver MH, Ukropcova B, Deutsch WA, Smith SR \& Ravussin E 2007 Calorie restriction increases muscle mitochondrial biogenesis in healthy humans. PLoS Medicine 4 e76. (doi:10. 1371/journal.pmed.0040076)

Cohen HY, Miller C, Bitterman KJ, Wall NR, Hekking B, Kessler B, Howitz KT, Gorospe M, de Cabo R \& Sinclair DA 2004 Calorie restriction promotes mammalian cell survival by inducing the SIRT1 deacetylase. Science 305 390-392. (doi:10.1126/science.1099196)

Considine RV, Cooksey RC, Williams LB, Fawcett RL, Zhang P, Ambrosius WT, Whitfield RM, Jones R, Inman M, Huse J et al. 2000 Hexosamines regulate leptin production in human subcutaneous adipocytes. Journal of Clinical Endocrinology and Metabolism 85 3551-3556. (doi:10.1210/jc.85.10. 3551)

D'Alessandris C, Andreozzi F, Federici M, Cardellini M, Brunetti A, Ranalli M, Del Guerra S, Lauro D, Del Prato S, Marchetti P et al. 2004 Increased $\mathrm{O}$-glycosylation of insulin signaling proteins results in their impaired activation and enhanced susceptibility to apoptosis in pancreatic beta-cells. FASEB Journal 18 959-961. (doi:10.1096/fj.03-0725fje)

Daniels MC, Ciaraldi TP, Nikoulina S, Henry RR \& McClain DA 1996 Glutamine:fructose-6-phosphate amidotransferase activity in cultured human skeletal muscle cells: relationship to glucose disposal rate in control and non-insulin-dependent diabetes mellitus subjects and regulation by glucose and insulin. Journal of Clinical Investigation 97 1235-1241. (doi:10. 1172/JCI118538)

Daugaard M, Rohde M \& Jaattela M 2007 The heat shock protein 70 family: highly homologous proteins with overlapping and distinct functions. FEBS Letters 581 3702-3710. (doi:10.1016/j.febslet.2007.05.039)

Dioum EM, Chen R, Alexander MS, Zhang Q, Hogg RT, Gerard RD \& Garcia JA 2009 Regulation of hypoxia-inducible factor 2alpha signaling by the stress-responsive deacetylase sirtuin 1. Science 324 1289-1293. (doi:10. 1126/science.1169956) 
Einstein FH, Fishman S, Bauman J, Thompson RF, Huffman DM, Atzmon G, Barzilai N \& Muzumdar RH 2008 Enhanced activation of a "nutrientsensing" pathway with age contributes to insulin resistance. FASEB Journal 22 3450-3457. (doi:10.1096/fj.08-109041)

Gagarina V, Gabay O, Dvir-Ginzberg M, Lee EJ, Brady JK, Quon MJ \& Hall DJ 2010 SirT1 enhances survival of human osteoarthritic chondrocytes by repressing PTP1B and activating the IGF receptor pathway. Arthritis and Rheumatism 62 1383-1392. (doi:10.1002/art.27369)

Gao Y, Miyazaki J \& Hart GW 2003 The transcription factor PDX-1 is post-translationally modified by $\mathrm{O}$-linked $\mathrm{N}$-acetylglucosamine and this modification is correlated with its DNA binding activity and insulin secretion in min6 beta-cells. Archives of Biochemistry and Biophysics 415 155-163. (doi:10.1016/S0003-9861(03)00234-0)

Guarente L 2008 Mitochondria - a nexus for aging, calorie restriction, and sirtuins? Cell 132 171-176. (doi:10.1016/j.cell.2008.01.007)

Guinez C, Mir AM, Dehennaut V, Cacan R, Harduin-Lepers A, Michalski JC \& Lefebvre T 2008 Protein ubiquitination is modulated by O-GlcNAc glycosylation. FASEB Journal 22 2901-2911. (doi:10.1096/fj.07-102509)

Hanley SC, Austin E, Assouline-Thomas B, Kapeluto J, Blaichman J, Moosavi M, Petropavlovskaia M \& Rosenberg L 2010 \{beta\}-Cell mass dynamics and islet cell plasticity in human type 2 diabetes. Endocrinology 151 1462-1472. (doi:10.1210/en.2009-1277)

Hebert LF Jr, Daniels MC, Zhou J, Crook ED, Turner RL, Simmons ST, Neidigh JL, Zhu JS, Baron AD \& McClain DA 1996 Overexpression of glutamine:fructose-6-phosphate amidotransferase in transgenic mice leads to insulin resistance. Journal of Clinical Investigation 98 930-936. (doi:10. 1172/JCI118876)

Kaneto H, Xu G, Song KH, Suzuma K, Bonner-Weir S, Sharma A \& Weir GC 2001 Activation of the hexosamine pathway leads to deterioration of pancreatic beta-cell function through the induction of oxidative stress. Journal of Biological Chemistry 276 31099-31104. (doi:10.1074/jbc. M104115200)

Kanfi Y, Peshti V, Gozlan YM, Rathaus M, Gil R \& Cohen HY 2008 Regulation of SIRT1 protein levels by nutrient availability. FEBS Letters 582 2417-2423. (doi:10.1016/j.febslet.2008.06.005)

Kim HS, Kim EM, Lee J, Yang WH, Park TY, Kim YM \& Cho JW 2006 Heat shock protein 60 modified with $O$-linked $N$-acetylglucosamine is involved in pancreatic beta-cell death under hyperglycemic conditions. FEBS Letters 580 2311-2316. (doi:10.1016/j.febslet.2006.03.043)

Konrad RJ, Mikolaenko I, Tolar JF, Liu K \& Kudlow JE 2001 The potential mechanism of the diabetogenic action of streptozotocin: inhibition of pancreatic beta-cell $\mathrm{O}-\mathrm{GlcNAc}$-selective $\mathrm{N}$-acetyl-beta-D-glucosaminidase. Biochemical Journal 356 31-41. (doi:10.1042/0264-6021:3560031)

Lee JH, Song MY, Song EK, Kim EK, Moon WS, Han MK, Park JW, Kwon KB \& Park BH 2009 Overexpression of SIRT1 protects pancreatic betacells against cytokine toxicity by suppressing the nuclear factor-kappaB signaling pathway. Diabetes 58 344-351. (doi:10.2337/db07-1795)

Lin SJ, Defossez PA \& Guarente L 2000 Requirement of NAD and SIR2 for life-span extension by calorie restriction in Saccharomyces cerevisiae. Science 289 2126-2128. (doi:10.1126/science.289.5487.2126)

Monauni T, Zenti MG, Cretti A, Daniels MC, Targher G, Caruso B, Caputo M, McClain D, Del Prato S, Giaccari A et al. 2000 Effects of glucosamine infusion on insulin secretion and insulin action in humans. Diabetes 49 926-935. (doi:10.2337/diabetes.49.6.926)

Moynihan KA, Grimm AA, Plueger MM, Bernal-Mizrachi E, Ford E, CrasMeneur C, Permutt MA \& Imai S 2005 Increased dosage of mammalian Sir2 in pancreatic beta cells enhances glucose-stimulated insulin secretion in mice. Cell Metabolism 2 105-117. (doi:10.1016/j.cmet.2005.07.001)

Nedachi T, Kadotani A, Ariga M, Katagiri H \& Kanzaki M 2008 Ambient glucose levels qualify the potency of insulin myogenic actions by regulating SIRT1 and FoxO3a in C2C12 myocytes. American Journal of Physiology. Endocrinology and Metabolism 294 E668-E678. (doi:10.1152/ajpendo.00640.2007)

Nisoli E, Tonello C, Cardile A, Cozzi V, Bracale R, Tedesco L, Falcone S, Valerio A, Cantoni O, Clementi E et al. 2005 Calorie restriction promotes mitochondrial biogenesis by inducing the expression of eNOS. Science $\mathbf{3 1 0}$ 314-317. (doi:10.1126/science.1117728)
Okuyama R \& Yachi M 2001 Cytosolic O-GlcNAc accumulation is not involved in beta-cell death in HIT-T15 or Min6. Biochemical and Biophysical Research Communications 287 366-371. (doi:10.1006/bbrc.2001.5607)

Picard F, Kurtev M, Chung N, Topark-Ngarm A, Senawong T, Machado De Oliveira R, Leid M, McBurney MW \& Guarente L 2004 Sirt1 promotes fat mobilization in white adipocytes by repressing PPAR-gamma. Nature $\mathbf{4 2 9}$ 771-776. (doi:10.1038/nature02583)

Pouwels MJ, Jacobs JR, Span PN, Lutterman JA, Smits P \& Tack CJ 2001 Short-term glucosamine infusion does not affect insulin sensitivity in humans. Journal of Clinical Endocrinology and Metabolism 86 2099-2103. (doi:10.1210/jc.86.5.2099)

Rossetti L, Hawkins M, Chen W, Gindi J \& Barzilai N 1995 In vivo glucosamine infusion induces insulin resistance in normoglycemic but not in hyperglycemic conscious rats. Journal of Clinical Investigation 96 132-140. (doi:10.1172/JCI118013)

Shankar RR, Zhu JS \& Baron AD 1998 Glucosamine infusion in rats mimics the beta-cell dysfunction of non-insulin-dependent diabetes mellitus. Metabolism 47 573-577. (doi:10.1016/S0026-0495(98)90242-6)

Sun C, Zhang F, Ge X, Yan T, Chen X, Shi X \& Zhai Q 2007 SIRT1 improves insulin sensitivity under insulin-resistant conditions by repressing PTP1B. Cell Metabolism 6 307-319. (doi:10.1016/j.cmet.2007. 08.014)

Tanno M, Sakamoto J, Miura T, Shimamoto K \& Horio Y 2007 Nucleocytoplasmic shuttling of the NAD +-dependent histone deacetylase SIRT1. Journal of Biological Chemistry 282 6823-6832. (doi:10.1074/jbc. M609554200)

Vanderford NL, Andrali SS \& Ozcan S 2007 Glucose induces MafA expression in pancreatic beta cell lines via the hexosamine biosynthetic pathway. Journal of Biological Chemistry 282 1577-1584. (doi:10.1074/jbc. M605064200)

Veerababu G, Tang J, Hoffman RT, Daniels MC, Hebert LF Jr, Crook ED, Cooksey RC \& McClain DA 2000 Overexpression of glutamine: fructose6-phosphate amidotransferase in the liver of transgenic mice results in enhanced glycogen storage, hyperlipidemia, obesity, and impaired glucose tolerance. Diabetes 49 2070-2078. (doi:10.2337/diabetes.49.12.2070)

Wang C, Chen L, Hou X, Li Z, Kabra N, Ma Y, Nemoto S, Finkel T, Gu W, Cress WD et al. 2006 Interactions between E2F1 and SirT1 regulate apoptotic response to DNA damage. Nature Cell Biology 8 1025-1031. (doi:10.1038/ncb1468)

Westerheide SD, Anckar J, Stevens SM Jr, Sistonen L \& Morimoto RI 2009 Stress-inducible regulation of heat shock factor 1 by the deacetylase SIRT1. Science 323 1063-1066. (doi:10.1126/science.1165946)

Yamamoto H, Schoonjans K \& Auwerx J 2007 Sirtuin functions in health and disease. Molecular Endocrinology 21 1745-1755. (doi:10.1210/me.20070079)

Yang Y, Fu W, Chen J, Olashaw N, Zhang X, Nicosia SV, Bhalla K \& Bai W 2007 SIRT1 sumoylation regulates its deacetylase activity and cellular response to genotoxic stress. Nature Cell Biology 9 1253-1262. (doi:10. 1038/ncb1645)

Yoshikawa H, Tajiri Y, Sako Y, Hashimato T, Umeda F \& Nawata H 2002 Glucosamine-induced beta-cell dysfunction: a possible involvement of glucokinase or glucose-transporter type 2. Pancreas 24 228-234. (doi:10. 1097/00006676-200204000-00004)

Zachara NE \& Hart GW 2004 O-GlcNAc a sensor of cellular state: the role of nucleocytoplasmic glycosylation in modulating cellular function in response to nutrition and stress. Biochimica et Biophysica Acta 1673 13-28. (doi:10.1016/j.bbagen.2004.03.016)

Received in final form 23 September 2010 Accepted 5 October 2010 Made available online as an Accepted Preprint 5 October 2010 